\title{
"A definite feeling of antagonism": Rising Tensions over Clothing at the Featherston Prisoner-of-War Camp in World War Two
}

\author{
KRISTYN HARMAN
}

\begin{abstract}
This article utilises negotiations around the clothing issued to Japanese prisoners of war during World War Two as a lens through which to view aspects of the social history of the Featherston Camp. A particular focus is the prisoners' objections to the requirement that they wear distinguishing khaki patches. Such objections went beyond being merely verbal, translating into physical interventions to modify their uniforms. The article demonstrates that tensions at the Camp continued well beyond the 1943 riot, and were not solely the province of the prisoners. Some attention is also given to New Zealand efforts at cultural accommodation and understanding.
\end{abstract}

Michiharu Shinya, a 22 year-old torpedo officer on the Japanese destroyer Akatsuki, was taken prisoner by the Americans at Guadalcanal on 13 November 1942. Being captured was, as Shinya later explained in his book-length account of his experiences as a prisoner of war, "above everything we Japanese fighting men traditionally regarded as the most unbearable shame." "1 Guadalcanal and the Solomon Islands have been described as a "hellhole of jungle warfare and tropical disease," and were sites of intense fighting between the Americans and Japanese from August 1942 until January 1943. The action saw 30,000 Japanese deaths. Eventually, Shinya was shipped to New Zealand early in 1943 together with other Japanese prisoners of war. Despite a fellow prisoner's fears that "we were being transported to hard labour in mountain coalmines," the train on which Shinya and his companions were conveyed after arriving in Auckland was destined for Featherston in the farming valley of Wairarapa, in the lower North Island. ${ }^{2}$ During World War Two, at the request of its American allies and at short notice, in 1942 New Zealand had established a prisoner-of-war camp 2.5 kilometres east of Featherston at the site of the country's largest former World War One training camp within which the predominantly Japanese prisoners taken during the Pacific War could be interned. ${ }^{3}$ It was the first site in the British Commonwealth to receive a large cohort of Japanese prisoners. A camp originally built 3 kilometres from Cowra in New South Wales, Australia, in 1941 to house Italian prisoners of war taken in North Africa, began to function as a repository for Japanese prisoners from January 1943, although following a break out on 5 August 1944, many of the surviving Japanese prisoners were moved north to Hay or south to Murchison in Victoria. ${ }^{4}$ More than 2,500 Japanese prisoners of war captured while fighting at the Arakan, Imphal, and Kohima (Burma) fronts were imprisoned in India between 1942 and 1946, while beyond the Commonwealth 5,424 Japanese prisoners were housed in camps in the United States (only 52 of whom were captured in the Pacific War). ${ }^{5}$ At the conclusion of the SovietJapanese War, an unprecedented 600,000 Japanese prisoners were sent to camps in Siberia in the former Union of Soviet Socialist Republics. ${ }^{6}$

On arriving at the Featherston camp, Shinya observed "a crowd of men in strange black hats and black clothing milled around within the enclosure" who, as he "looked more carefully," he recognised as "Japanese POWs."7 The arrival of the Japanese Officers heralded a transition at the Camp which had previously been a repository solely for enlisted men, or "the workers," many of whom had been conscripted, and whose peacetime occupations ranged from fishermen and rice sellers, to farmers, carpenters and stonemasons. ${ }^{8}$ The career military men were nowhere near as compliant as their civilian counterparts with the camp guards' efforts to extract 
labour from them. Despite the New Zealand military hierarchy being concerned that the working class guards with their very limited knowledge of Japanese culture would class "the Japs... with other orientals of a more submissive slave temperament" rather than recognising them as belonging to "a very vain, arrogant, aggressive and capable race," the guards dubbed the officer class "the fighting men." If not completely au fait with racial stereotypes current at the time, the guards nevertheless distinguished these new arrivals from their more compliant countrymen. The guards' awareness of this difference, however, did not enable them to curb the rising tensions which ultimately led to a riot at the Featherston Camp on 22 February 1943. As a result of this riot, forty-eight prisoners and one guard lost their lives. This incident has attracted more scholarly attention than any other aspect of camp life, often being discussed together with the 1944 break out from the Japanese prisoner-of-war camp at Cowra. ${ }^{10}$ Researchers including the late Eric Thompson, Charlotte Carr-Gregg, and Mike Nicolaidi have concluded that the conflict at the Featherston Camp was "the culmination of mutual misunderstandings." 11

Less well remembered than the riot are tensions at the Featherston Camp that arose in July 1944 in relation to the prisoners' issued clothing. At the Featherston camp, Japanese prisoners generally, and the officer class in particular, strongly objected to an edict requiring them to wear specially "patched" (marked) clothing. These objections went beyond being merely verbal, translating into physical interventions by some Japanese prisoners to modify the uniforms issued to them by the New Zealand Army. Such interventions were viewed by the military hierarchy as evidence of the "Jap's lack of moral sense," as the prisoners saw "nothing wrong in cutting up garments, boots, etc. to make other articles," as will be explored later in this article. ${ }^{12}$ Imbued with both practical and symbolic importance, clothing served necessary purposes related to regulating body temperature and complying with cultural mores around modesty as well as denoting status. In situations of captivity, the prisoners' embodied experiences are shaped by a combination of their inner attitudes and external factors such as the shelter, food, and clothing with which they are provided, and the labour or other activities in which they are engaged. Yet, to date, little scholarly attention has been given to the clothing with which Japanese prisoners of war were issued, either at the Featherston camp or in international comparative contexts. Despite the difficulties inherent in "translating the nonverbalized experiences of clothes in use into written academic language," investigating camp life through the medium of clothing reveals a long-neglected key locus of contestation and submission with regard to Japanese incarceration at the Featherston camp. ${ }^{13}$ It also facilitates an exploration of New Zealand perceptions of the prisoners' inner life based on the views of the military hierarchy within and beyond the camp to the prisoners' responses to the clothing with which they were issued. Examining the various issues that arose around modifications to this clothing by both the New Zealand Army and the Japanese prisoners themselves facilitates an exploration of New Zealand attempts to clearly identify, regulate, and discipline the prisoners, as well as the prisoners' exercise of agency within the constraints of camp life. This article also demonstrates how power struggles were not only clearly evident at the camp, but also arose between the New Zealand Army officers tasked with overseeing the daily operation of the Featherston Camp and senior staff based at Army Headquarters in Wellington.

In accordance with the provisions of Chapter Two, Article 12, of the Convention Relative to the Treatment of Prisoners of War prepared by the International Red Cross and signed at a Diplomatic Conference convened in Geneva in 1929, New Zealand as the detaining power was responsible for supplying clothing, underwear, and footwear to the Japanese prisoners of war. ${ }^{14}$ Accordingly, on 14 September 1942, Lieutenant-Colonel Burge wrote on behalf of the Quartermaster General to the Commandant at the Featherston Camp to confirm approval of the issuing of "clothing and necessaries" to the prisoners. In addition to receiving a kit bag, the 
men were to be provided with a toothbrush and paste, four blankets, a greatcoat, felt hat, jacket, jersey, two flannel shirts, a pair of trousers and braces, two vests and two pairs of drawers, a pair of boots, three pairs of woollen socks, five handkerchiefs, a knife, fork, spoon, tin plate, and pannikin, a palliasse (straw mattress), and two towels. The prisoners were also allowed to be issued with leather sandals on the medical officer's recommendation. Each prisoner was, at this stage, also allowed to be issued with a housewife (sewing kit). ${ }^{15}$ Little has been written in comparative contexts about the clothing issued to Japanese prisoners, although some of those imprisoned in India were supplied with similar items to those in New Zealand. While the kit supplied to Japanese prisoners of war in India varied, at least some are described by Tilak Sareen as having been issued with "woollen jackets, shirts and pullovers" as well as "woollen vests or cotton vests, trousers, pairs of socks and a pair of shoes." Sareen has explained how those who were required to engage in labour outside were also provided with an overcoat. ${ }^{16}$

One of Shinya's first memories about having arrived at the Featherston Camp was of how "they issued us with clothing and eating utensils." He described these items as "extremely plain," and took them to be an indication of "the difference between the American and this British way of doing things." From the perspective of a Japanese officer, "the atmosphere [at the Featherston Camp] was completely down-to-earth, simple and rustic." ${ }^{17}$ Nicolaidi has described how the clothing provided to the Japanese prisoners of war "included New Zealand army uniforms circa 1914-18 dyed dark blue, and boots." The headwear that they were issued was also dark blue, and comprised "the traditional army 'lemon squeezer," although as Eric Thompson has explained, "later issues were sometimes Second World War battledress [and] the Japanese usually wore the hats with a round dish on top," as seen in surviving photographs of prisoners working at, and beyond, the camp. ${ }^{18}$ Recycling army surplus clothing from the First World War was a relatively inexpensive and efficient way to meet the clothing needs of these prisoners of war who had arrived on New Zealand's shores at such short notice.

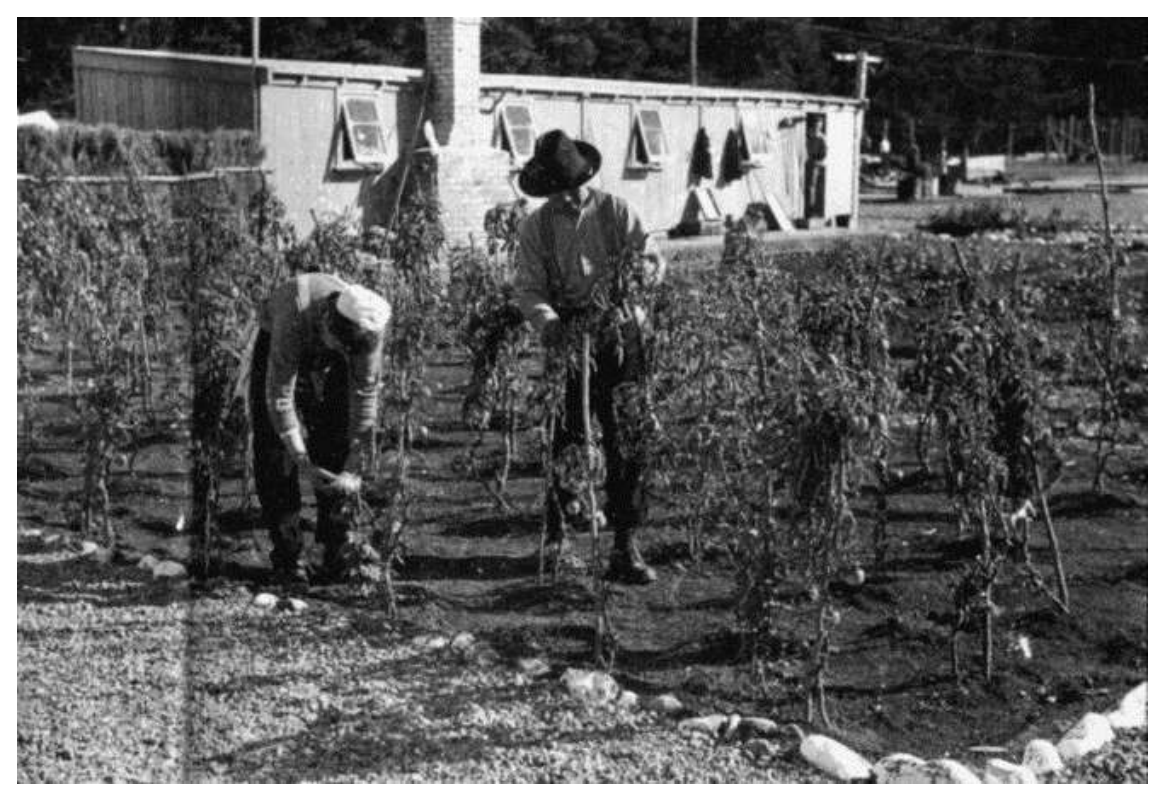

Fig. 1: View of the camp for Japanese prisoners of war at Featherston, taken c. 1943 by an army photographer. ${ }^{19}$

Permission of the Alexander Turnbull Library, Wellington, New Zealand, must be obtained before any reuse of this image. 
Responsibility for issuing clothing and supplies to the prisoners fell to the Camp's Quartermaster, a position held for a time by Norman Grenfell. Formerly a Wellington-based clerk, on being called up for military service Grenfell was found to have flat feet which precluded him from serving overseas. Nevertheless, he was quickly promoted up through the ranks and became a commissioned officer prior to being sent on a quartermasters' training course. Owing to friction between the Commandant and the Quartermaster at the Featherston camp, Grenfell was instructed to replace the latter. ${ }^{20}$ At the camp, the prisoners of war could return worn out articles and have them exchanged by the Quartermaster, provided that they washed the articles before returning them. They could also, at the written recommendation of the Camp's Medical Officer, have additional items issued to them as and when required for health reasons. ${ }^{21}$

Just a week after the Quartermaster General approved the issue of kit to the prisoners of war, a brief communication was sent from his office to the Featherston Camp on the topic of "distinguishing patches and armlets for POW." In it, the Camp officials were informed that the Chief Ordnance Officer thought that "white paint in the form of a diamond or square, with black numbers superimposed" would be a preferable method through which the Japanese men might be identified as prisoners. "This," said the Chief Ordnance Officer, "would do away with the necessity for armlets." It was presumably also considered to be a more cost-effective measure, and involved the Camp staff being instructed to forward an indent for two sets of "the necessary stencils." 22 Over the months that followed, several issues in relation to the prisoners' clothing arose, one of which was only hinted at in a brief memo dated 18 December 1942, sent from the Quartermaster General to the Featherston Camp to confirm the details of a telephone conversation earlier that same day. In his memo, the Quartermaster General ordered the return of all housewives intended for the Japanese prisoners to the Main Ordnance Depot, and also wanted to know how many had already been issued. ${ }^{23}$ The reasons for this were not immediately apparent from the surviving archival evidence, but could have related to issues such as the potential use of sharp items such as scissors or needles as weapons, the costs involved in issuing these kits to the prisoners, and the capacity inherent in these kits for the prisoners to adapt their clothing and other items of kit to purposes other than those for which they were originally intended. In the interim, suffice it to say that on Christmas Day 1942, the Camp Quartermaster wrote back to Army Headquarters in Wellington to confirm that 690 housewives had been received from Trentham and subsequently issued to the prisoners. ${ }^{24}$

By early 1943, it had become apparent that the boots held in the Quartermaster's store at the Featherston Camp were insufficient in number to meet the demand on the part of the prisoners. Writing to Army Headquarters to confirm that the boots in question were indeed being issued to the prisoners rather than to staff, the Camp Quartermaster noted that while 75 pairs of boots were in transit to be added to the 125 pairs already held in stock for the sole purpose of exchange, the resulting 200 pairs of boots "will not be sufficient to cope with the rate at which the Japanese wear their boots out." He attributed this to the hard ground at the Camp, the nature of the manual labour in which the prisoners were engaged, and his observation that "the Japanese have a very slovenly way of walking," describing this as being "actually ... more of a shuffle than a walk." ${ }^{25}$ In fact, the principle reason behind the extreme wear and tear experienced by the prisoners with regard to their boots had a much more prosaic, if not immediately apparent, explanation. "We seemed to be getting far too many burned boots," Grenfell is reported as later having said in an interview. "This worried me. I talked about it with the other officers." On realising what was behind the burnt boots, one of the other officers took the quartermaster into one of the prisoners' compounds where: 
In the cookhouse they had great big metal stoves which were oil fuelled. The tops were just about red hot and the Japs were hopping up on top to shift the dixies of rice around and that's how their boots were getting burned.

The problem of trying to cook rice using the stoves available at the camp was probably not something to which the military would have given much thought, as in the middle decades of the twentieth century most New Zealanders' experiences of preparing and consuming this grain was limited to the occasional rice pudding. Nevertheless, shortly after perceiving the problem behind the all too frequently worn out boots, Grenfell came up with a solution. As the camp had a furniture factory from which one of the by-products was offcuts of wood, he suggested that the prisoners be allowed to make their own "getas," or traditional Japanese wooden-soled sandals that they could wear instead of boots. As the quartermaster said, "[a]11 it needed was some spare bits of 4 by 2 . The Japs used to like walking around in them. They were used to them at home." ${ }^{26}$ The popularity of these wooden sandals was such that the Japanese officers asked if they, too, might be issued with them. ${ }^{27}$ This episode in camp life shows how, once the issues around cooking practices and the associated wear and tear on army-issued boots was understood, an innovative solution that met the prisoners' practical and cultural needs, helped ease some of their tensions, and appeased Army Headquarters could be implemented.

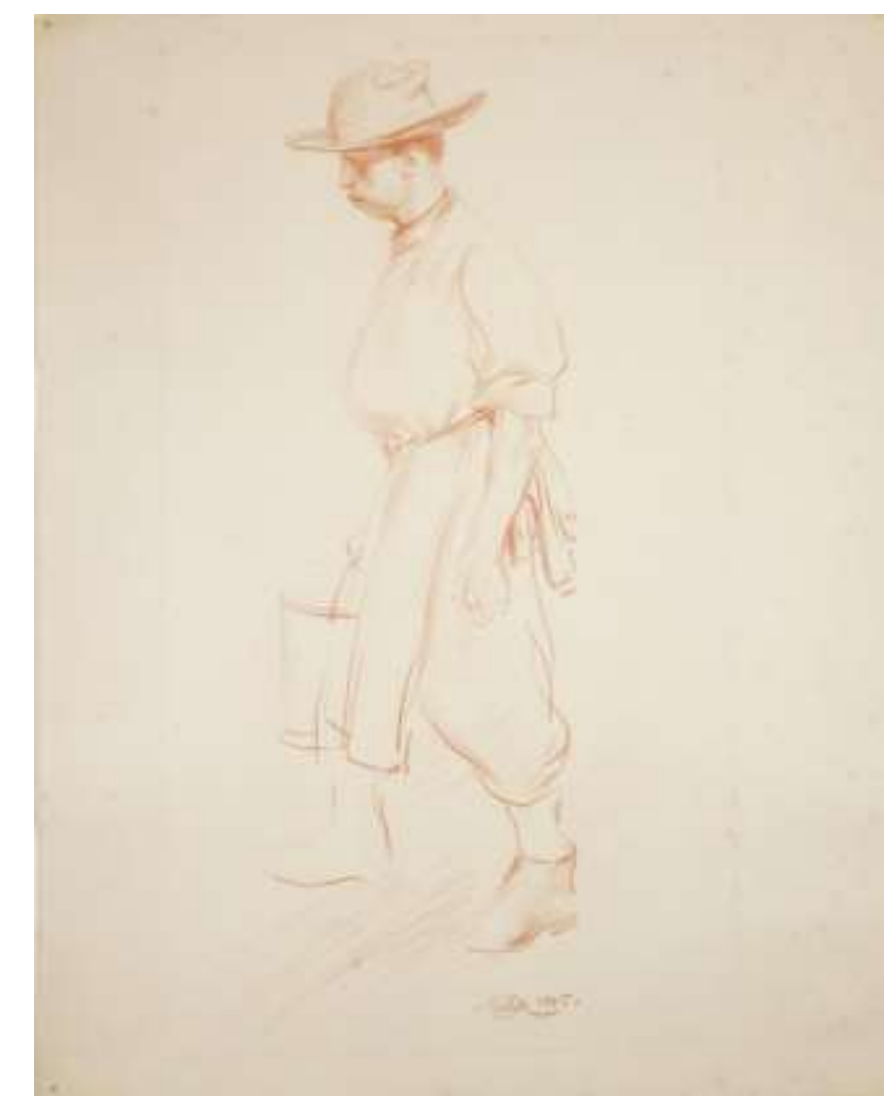

Fig. 2: "Prisoner with apron and bucket," sketched by Victor Mitchell, one of the Camp guards. ${ }^{28}$

This image has been reproduced with kind permission from the artist's brother, Frank Mitchell. 
In the same memorandum in which the Quartermaster raised the issue of the "over worn boots," he also brought another "acute" matter to the attention of Army Headquarters. Under the provisions of the Geneva Convention of 1929, two copies of which (written in Japanese characters) were supplied to the Featherston Camp in February 1944, prisoners of war were allowed to be put to labour provided that their labour did not contribute directly to the war efforts of the detaining power (such as would be the case, for example, in the manufacture of munitions). At, and beyond the boundaries of, the Featherston Camp, the prisoners were involved in a range of manual labour. This included working in market gardens (under guard) at nearby Greytown, labouring in a nearby piggery, working onsite in the concrete works or furniture factory, or winding jute. ${ }^{29}$ The pair of former World War One trousers which each prisoner was allowed was not proving sufficiently robust under the circumstances in which they were required to be worn. As only one pair was able to be issued in the first place, the Japanese prisoners "practically live[d] in" them. "Being old material," the Quartermaster reported, the trousers "are splitting at the knees and at the seat and becoming so thin and threadbare, practically all over, that it is next to impossible to repair them." Perhaps resorting to old stock with weakened fabric fibres was proving to be an act of false economy. In any case, the Quartermaster sought permission to issue each prisoner with a second pair of trousers. ${ }^{30} \mathrm{He}$ later proposed that all of the old jackets and trousers that were stockpiled at the camp could be repurposed "into repair material" that the prisoners might use to repair their clothing. ${ }^{31}$

With the removal of housewives, the prisoners of war had lost the capacity to carry out their own repairs. This led to the Camp Commandant suggesting to Headquarters that a tailor's shop be established at the Featherston Camp which could be equipped with a sewing machine, needles and thread, and repair material which, he proposed, "could be manned entirely by prisoners" working on repairing the uniforms. Such was the situation with regard to the men's trousers that it was "in the interests of decency" that he, too, sought permission for a second pair of trousers to be issued to each of the prisoners. ${ }^{32}$ Despite the urgency of his request, a week later the Commandant was told that the question as to whether additional trousers could be issued had not yet been decided on, although each prisoner was to be allowed a second pair of boots. ${ }^{33}$ Indeed, it was not until four months later, in April 1943, that the Featherston Camp received advice that the Chief Ordnance Officer was arranging for more clothing so that a second pair of trousers might be issued to each of the prisoners. A side issue as to whether the prisoners might be allowed to utilise khaki trousers and overalls provided to them by the Americans, but since withdrawn by the New Zealand military, was also resolved with a decision being taken to dye the garments blue and reissue them. Denim clothing was also to be made available for use when particularly dirty jobs were demanded of the prisoners, such as working at the piggery, for example. ${ }^{34}$ Despite the best efforts of staff at the camp itself, the wheels of officialdom turned slowly with regard to meeting the prisoners' clothing needs. Army Headquarters was clearly committed to ensuring that the prisoners were dressed solely in the navy blue clothing with which they had been issued, and that marked them as prisoners of war, with the sole exception of some working clothes, including denims, being made available for those who were routinely engaged in particularly dirty labour.

As early as 14 September 1942, the Camp Commandant had been left in no doubt as to the importance that the Quartermaster General placed on having each and every item issued from his stores carefully and accurately accounted for in the requisite paperwork. In practice, this translated into instructions such as that issued by the Quartermaster General to the Commandant, requiring the latter "in the event of the death of a POW" who had "any articles buried with him," to ensure that such articles of kit were formally written off, and signed off by the Commandant himself. ${ }^{35}$ In cases where the prisoners of war needed to exchange worn out items for newly-issued ones, they were required to attend clothing and boot change parades. 
These were convened on a weekly basis, at 9:00 am on Saturday mornings in Compounds No. 2 and No. 3 for military force prisoners and officers, and at 1:30 pm later the same day in Compound No. 1 where many of the labouring prisoners were housed. ${ }^{36}$ To better discipline them, the prisoners had been housed in separate compounds following the infamous riot, with the officers and those who resisted work orders being separated into their respective compounds to be kept apart from the remaining men. ${ }^{37}$ As many as one hundred prisoners accompanied by only one or two guards would march down to the Quartermaster's store where, as Grenfell later explained, three of his Japanese assistants would change the old garments for new ones. The prisoners would then be marched back to their compounds. ${ }^{38}$ Despite the worn out garments being kept for mending less worn clothing, this was to be carried into effect only at the behest of the camp authorities.

Part of the disciplinary regime at the Featherston Camp saw the prisoners prohibited from utilising worn out clothing for repairs carried out at their own initiative, or as cleaning rags, or indeed "for any other purpose." Part of the reasoning behind the rapid withdrawal of housewives from the prisoner of war population is evident in a short notice circulated in Japanese to each of the Camp Compounds on 4 May 1943. The English version clearly states that "many articles of issue are being mutilated by Prisoners of War, especially towels which are torn up and made into caps, bags and sundry other small articles." The prisoners were informed that "this practice of mutilating issue clothing must stop." 39 It seems likely that some of the sundry articles being cut and stitched by the prisoners may have been bags created to hold Japanese dietary staples such as rice and tea leaves, as a minute sheet from the previous month indicates that such bags had been requested but were not yet being supplied for the prisoners' use. $^{40}$ As former Camp Guard Lieutenant Dave Gillies later explained, following the February 1943 riot "conditions for the prisoners were improved, especially by providing food more suitable for the Japanese diet." ${ }^{41}$ The prisoners had requested greater variety, including more fish and vegetables, and the addition of curry powder, Worcester sauce, vinegar, and tomato ketchup (sauce). They also sought to swap what was, for them, a useless ration of oatmeal for additional rice. ${ }^{42}$ The addition of commodities such as rice created a need on the part of the prisoners to be able to store it, a demand that the Featherston Camp officials would meet only through the official channels of requesting additional kit. Despite Gillies later attributing the post-riot changes such as adapting the prisoners' rations with ensuring that "there were no further violent incidents in the camp," this was not the case. ${ }^{43}$ However, the violent incident that culminated from rising tensions at the Featherston Camp in mid-1944 was on a much smaller scale than the infamous riot of the previous year.

The parsimonious attitude of the military hierarchy towards the kit provided for the use of the prisoners of war is also evident in a memorandum issued the following year, on 24 March 1944. The Camp Commandant was told that he was "authorised to experiment on up to six uniforms" to test the feasibility of making "a distinctive mark on each garment" that "could be applied by use of a stencil and paint (preferably yellow paint)." This potentially provided a faster alternative to sewing on the required marks. ${ }^{44}$ The decision to have the prisoners' clothing marked in such a way was taken following the escape from the camp of Prisoner Number 222, a man nicknamed "twos loose" by the guards, apparently after a card game that they played. ${ }^{45}$ As Shinya later explained, "only the barbed wire palisades formed a boundary between the world of the free, on the one hand, and our existence of captivity, on the other." 46 Seeking to return to the free world beyond the barbed wire, Prisoner 222, a dock labourer named Hisao Kobayashi aged 24 when his details were recorded, managed to breach several security fences, including the perimeter fence, before being retaken. ${ }^{47}$ The Court of Inquiry held to investigate Kobayashi's escape expressed concerns that an escaped prisoner of war might be mistaken for a civilian carrying out duties around the camp, or might be hard to see 
clearly against dark backgrounds. It was concerns such as these that led to an official decision to have the prisoners' uniforms marked with a distinguishing patch. ${ }^{48}$

The experiment with painting patches onto the prisoners' uniforms was not successful, although the archival records do not reveal the exact reasons behind its failure. The Quartermaster General decided that it would be necessary to revert to what had been the original plan of sewing a coloured patch to each garment. This process would involve the navy blue fabric beneath each of the khaki diamond-shaped patches being cut away. Despite this, it was the Quartermaster General's view that the modifications to the prisoners' garments did not need to be made by a tailor "but could be carried out by most anyone capable of handling a sewing machine and a pair of scissors." 49 In response, the Camp Commandant's terse reply was that "it is NOT possible to do this work from camp labour," highlighting tensions between the military staff responsible for the Featherston Camp and their Wellington-based superiors. The Commandant had apparently already made this point at a conference convened the previous month, on 21 March 1944, at District Headquarters. ${ }^{50}$ By 3 May 1944, the Quartermaster General had arranged for sample garments to be sent to the Featherston Camp. He had changed his view about who ought to make the alterations, stating that "the work of altering the garments now in possession of the prisoners of war at Featherston should be undertaken in the tailor's shop there." He anticipated that one set of clothing at a time would be retrieved from each prisoner to be marked. The patches were to be provided from Trentham, with the Chief Ordnance Officer also supplying a qualified tailor to supervise the process. ${ }^{51}$

While the New Zealand Army debated how best to mark the prisoners' uniforms, another matter had arisen regarding how the men were clothed. The Geneva Convention 1929 provided for officers who had been taken prisoner to continue to be paid their monthly salary while in captivity, with the detaining power eventually being reimbursed at the end of the war by the country to which the officers were repatriated. ${ }^{52}$ At the Featherston Camp, the Japanese officers sought permission to be allowed to use some of their credit to buy battle dress to wear as a means through which they might distinguish themselves from the remaining prisoners of war. The officers were prepared to have the battle dress dyed blue in keeping with the convention established at the Featherston Camp whereby the prisoners were dressed solely garments of that colour. The Commandant saw some benefit in this, as with all the prisoners dressed alike his guards had been experiencing some difficulties in differentiating the officers from the other prisoners. He therefore wrote to Army Headquarters on 15 April 1944, recommending that each officer be allowed to buy two sets of battledress. ${ }^{53}$ Permission for the officers to do so was granted on 4 May 1944, with a request being made by the Quartermaster General to be informed of the number and sizes of dyed battledress that would be required. ${ }^{54}$ Three sets would be supplied per officer, two to be issued and one held in reserve as replacement stock. Perhaps remembering the rather terse exchanges over who would be charged with the task of "patching" the prisoners' uniforms, the Commandant suggested that this be done by Ordnance prior to the clothing being sent to the Featherston Camp. ${ }^{55}$

By the end of the following month, further issues had emerged in relation to the proposed addition of distinguishing patches to the prisoners' uniforms. The officers in particular were adamant that they did not want to be made to wear such patches on their newly-arrived navy blue battledress. The Commandant gave them a sympathetic hearing, and recommended that the new regulation requiring the prisoners to wear a patch on their uniform ought not to apply to the Japanese officers. ${ }^{56}$ Such concerns among the prisoners clearly extended beyond the officers, as on 29 June 1944 Dr Bossard, the International Red Cross delegate in New Zealand, requested that the decision to adhere distinguishing khaki patches to the prisoners' jackets and trousers be reconsidered. Bossard was informed by the Adjutant General that the application of distinguishing patches would not be enforced for officers' clothing, and that consideration 
would also be given to excluding non-commissioned officers' clothes as well. Indeed, the Adjutant General discerned how the situation could work to the Army's advantage, advising the Commandant at the Featherston Camp that "it might well be politic to tell the NCOs that they would be excluded as a special privilege from this marking as it is felt that better cooperation might well result from such a step." ${ }^{, 57}$ Apparently no consideration was to be given to exempting conscripted Japanese men from the indignity of being made to wear the proposed distinguishing patches. In response, the Commandant pointed out that as the NCOs were often in charge of work parties within and beyond the Camp, either NCOs and other men ought all to wear the required patches, "or else the wearing of patched clothing should be dispensed with altogether." He did, however, confirm his view that the officers ought to be exempt from this requirement. ${ }^{58}$ Taking the Commandant's views into account, on 12 July 1944 the Adjutant General gave the order for the patching of the prisoners' clothing, with the exception of the officer class, to proceed. ${ }^{59}$

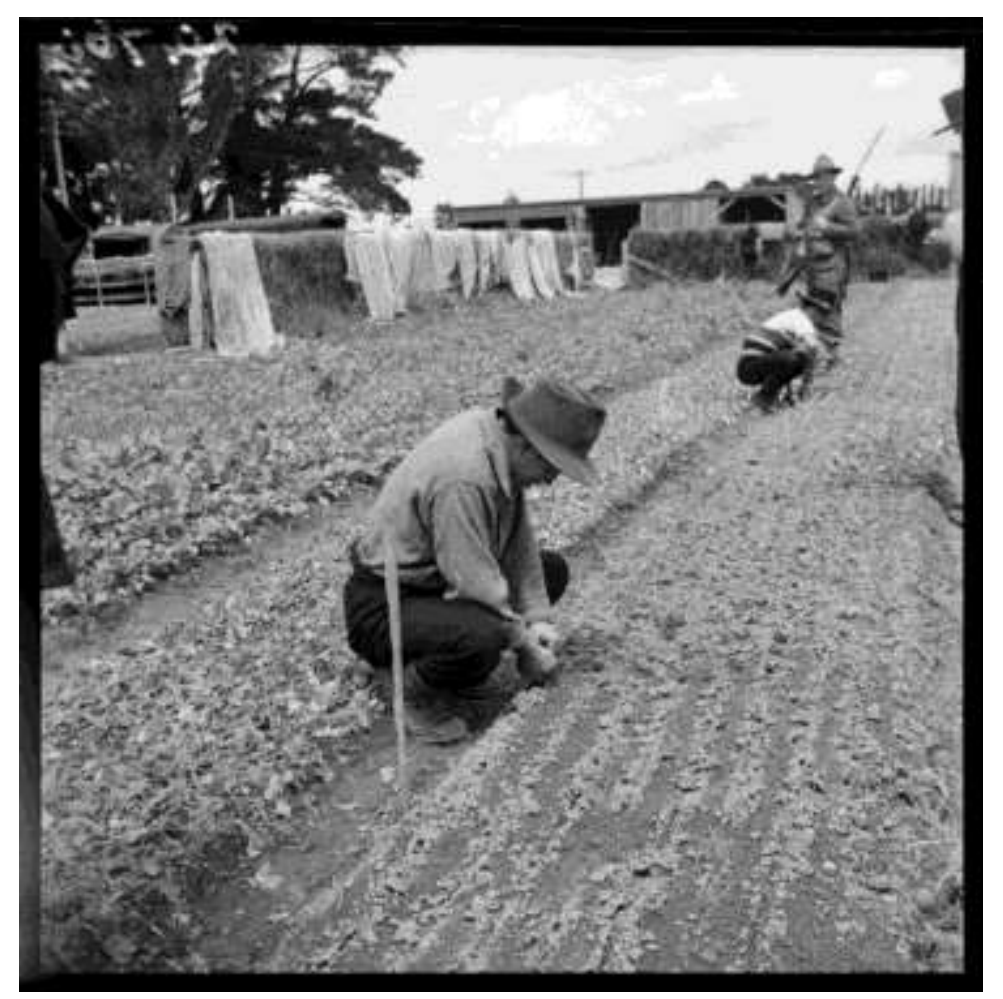

Fig. 3. Japanese prisoners of war planting cabbages at the state market gardens, near Featherston, in $1943 .{ }^{60}$

Permission of the Alexander Turnbull Library, Wellington, New Zealand, must be obtained before any reuse of this image.

Within just a few days of the order being given with regard to patching the prisoners' clothes, their displeasure at its implementation became sufficiently evident for the Commandant to convey his concerns to Army Headquarters in Wellington. He recalled how the patches were intended to improve security at the Featherston Camp, but wrote that he had since started to believe "that not a great deal is being achieved in this direction by the wearing of patched clothing." While the patches were supposed to make the prisoners more conspicuous, the Commandant ventured that "such action is really unnecessary as their blue uniforms and general appearance are so distinctive that there is very little possibility of their being mistaken 
for civilians employed in or around the Camp." Indeed, the newly-issued patched clothing was proving to be a threat to security. The prisoners themselves had "acted very unfavourably" towards the wearing of the clothing. Tensions were rising. The Commandant, who visited the compounds on a daily basis, had discerned "a definite feeling of antagonism." He chose two incidents that had transpired during the week leading up to 16 July 1944 to illustrate to his superiors just how serious the situation was becoming.

On Monday 10 July 1944, one of the prisoners of war had gone into the officers' compound where another of the prisoners happened to be working. The prisoner who had entered the compound gave his jacket to his fellow prisoner, who "cut therefrom the khaki patch." This prisoner was followed by another, employed as a Camp barber, and again the prisoner employed in the officers' compound cut the khaki patches from the man's top and trousers. ${ }^{61}$ As Shinya explained, "Japanese are clever with their fingers," and clearly on this occasion the prisoners had developed a process of their own for dealing effectively with the unwanted distinguishing marks that had recently been sewn into their uniforms. ${ }^{62}$ This behaviour was not allowed to continue unchecked. For providing this service to his fellow prisoners, the man wielding the scissors was sentenced to detention for twenty-one days. ${ }^{63} \mathrm{At}$ the time at which the Commandant was writing his letter, the man had been on a hunger strike since his confinement five days earlier. The day before the Commandant wrote to Army Headquarters, Lieutenant Garrett was Escort Officer and was checking the prisoners in No. 2 Compound at 7:05 am. As the parade ended, Garrett was writing up his notes as he walked away. He was attacked from behind, with his arms being pinioned to his sides. Fortunately, the officer was able to break free from this hold and, although he drew his pistol, the situation was able to be resolved without any shots being fired. He was shepherded to the gate under the watchful eye of the Orderly NCO (who was also armed, but who likewise did not fire his weapon), and to safety. ${ }^{64}$ The Commandant attributed both incidents to "our insistence that patched clothing must be worn." He took them as indications "that more serious trouble may eventuate in the future," and requested that consideration be given to withdrawing the instruction as to the wearing of the khaki patches. ${ }^{65}$

Despite the Commandant's concerns about the increasing antagonism being displayed by those Japanese prisoners who were now being forced to wear distinguishing patches on their clothing, he was informed by the Assistant Adjutant General that there would be no backing down, as to rescind such an order would be seen as "showing a sign of weakness on the part of Army." While the Assistant Adjutant General acknowledged that "unforseen repercussions may eventuate from the enforcement of the regulation," he insisted that it remain in place. The Commandant was instructed to ensure that his personnel were cautious about not placing themselves in any potentially vulnerable situations from which actions on the part of Japanese prisoners might arise that could lead to the latter becoming subject to "severe disciplinary measures." He also stressed the need to ensure that the prisoners be "made to feel that there is no 'loss of face' in the patching of their clothing." Such a procedure, he ventured, was "a custom throughout the world" as providing a visible means through which prisoners of war could be readily identified. ${ }^{66}$

The Assistant Adjutant General advised the Commandant to ensure that the prisoners were made well aware that "the patching of clothing is a purely normal procedure exercised by all other Powers." He also suggested that the prisoners could be told that the only reason that they had not been uniformed in such a way any earlier was because suitably identifiable clothing had not been available. ${ }^{67}$ As the prisoners themselves may have been only too well aware, the principle reason behind the change to their uniforms was that one of their fellow prisoners had escaped from the Camp and security was therefore being tightened. This really had nothing to do with the prior availability or otherwise of patched uniforms. It is nevertheless instructive to see the extent to which the Army were prepared to frame a response to the 
incidences at the Featherston Camp in July 1944 that took cultural factors (at least, as understood from a New Zealand Army perspective) into account, and that was designed to ensure that the Japanese prisoners of war could be assured that they were not being affronted in such a way as to result in a "loss of face." Japanese preoccupations with not wanting to be seen to have "lost face" were, like Japanese attitudes towards their issued clothing and to escaping from camp, associated by the military hierarchy with a "lack of moral sense" as it was considered to indicate that "Japs have no sense of guilt" and were only concerned about how their motives might be perceived by others. ${ }^{68}$

The Commandant at the Featherston Camp responded to the Assistant Adjutant General by reiterating that the prisoners had "reacted very unfavourably" to being made to wear identifying patches on their uniforms. He noted the "marked change in their attitude," despite the prisoners having repeatedly been assured that "there is no 'loss of face' involved." The Commandant put their apparent inability to acknowledge this down to "a different mental outlook" on the part of the Japanese prisoners. Informing the prisoners that adhering identifying patches to such clothing was a standard practice around the world had failed to sway their views about this imposition on them at the Featherston Camp. The Commandant concluded by disagreeing with a suggestion put forward from the Red Cross Delegate Bossard that the NCOs be allowed to have one set of patched and one set of unpatched clothing. He recommended either both sets be patched, or that the whole issue of enforcing the wearing of patched clothing be reviewed by the Army. ${ }^{69}$ Clearly, the military hierarchy had no intention of reviewing the requirement that the Japanese prisoners of war, excepting the officers, be required to wear identifying khaki patches on their army-issued clothing.

Presumably the order requiring the prisoners of war to wear patched clothing remained in force until 30 December 1945, the day on which the surviving men began their journey home to Japan. Shinya later recalled how before leaving the Featherston Camp he had handed in "my blankets and other items on loan," being left only with "my clothes and a pocketful of personal effects." At the railway station in Wellington, prior to being loaded onto two American navy vessels for the requisite sea journey, "our last farewell salutes were exchanged with the commandant, who had specially come to see us on our way, and with Dr Bossard of the Swiss Red Cross Society and the escorting soldiers." ${ }^{70}$ Perhaps at this stage any differences between the Commandant and Bossard over the application of patches to the NCOs' clothing faded into the background as both saw off those of their charges who had survived their incarceration as prisoners of war in the Featherston Camp.

Utilising the negotiations around the clothing issued by the New Zealand Army to the Japanese prisoners of war as a lens through which to view aspects of social history at the Featherston Camp during World War Two has revealed key elements of a power struggle that continued to play out between various cohorts connected with this site well beyond the aftermath of the 22 February 1943 riot. While high-ranking officers such as the Camp Commandant who were immersed in the daily operation of the Featherston Camp made recommendations to their superiors based to their observations on the ground, higher ranking officials at Army Headquarters in Wellington did not always concur with such recommendations, preferring a textbook approach that sometimes resulted in unforseen adverse outcomes. For example, in July 1944 at the Featherston Camp several prisoners of war responded adversely to the implementation of a new requirement that they be made to wear identifying patches on their uniforms. The way in which the Japanese officers were exempted from this requirement, and were instead allowed to purchase and wear navy blue-dyed battledress to distinguish themselves from the other prisoners, highlights the ongoing divisions that remained in place between the officers and conscripted men. It also demonstrates some sensitivity on the part of the New Zealand military hierarchy towards allowing symbolic differentiation between the 
ranks to be made visible through their clothing, even if only in an effort to maintain discipline at the camp in the aftermath of the riot, through keeping the Japanese officers reasonably contented and therefore under control.

The Japanese prisoners' response to the incorporation of identifying patches into their Army-issued tops and trousers demonstrates their exercise of agency within the constraints of the camp in that they appear to have set up a system whereby those particularly affected by the imposition could visit another of the prisoners who would remove the offending patches for them. Such acts of defiance stand testament to the fact that the prisoners were sufficiently antagonised by this imposition to risk incurring punishments for seeking redress. While the Commandant was sympathetic to the prisoners' feelings, he could not allow discipline to lapse on his watch and had little choice but to impose a punishment on the man wielding the scissors used to remove the khaki patches from the clothes of several of the prisoners'. Likewise, Army Headquarters did not want to be seen as weak through backing down on its requirement that the prisoners wear the identifying patches, even though, with the benefit of hindsight, the imposition was seen to be causing problems and to have had the potential to cause even bigger issues than those recorded.

Some flexibility towards the material needs of Japanese prisoners was, however, evident at a local level, as seen, for example, in the Featherston Camp Quartermaster's response to the issue of Japanese prisoners wearing their boots out too quickly through utilising them on the red hot iron plates on which they cooked their rice. Enabling the prisoners to make and later wear their own wooden sandals not only addressed the material issue of the worn out boots, but also demonstrated some knowledge of Japanese traditions and respect for Japanese cultural practices. Similar efforts to understand and engage with Japanese ways of being, particularly thought processes related to status and shame, in order to preserve camp discipline were also evident in the ways in which both Army Headquarters staff located in Wellington and Army personnel at the Featherston Camp sought to assure the prisoners of war that wearing the required identifying patches on their clothing would not result in "loss of face." Such assurances, though, did little to mollify those among the prisoners of war who were forced to wear the distinguishing khaki diamonds on their clothing until their eventual repatriation to Japan.

\footnotetext{
${ }^{1}$ Michiharu Shinya, Beyond Death and Dishonour: One Japanese at War in New Zealand (Auckland: Castle Publishing, 2001), 10; 16.

${ }^{2}$ Shinya, Beyond Death and Dishonour, 42-43.

${ }^{3}$ Neil Frances, Safe Haven: The Untold Story of New Zealand's Largest Ever Military Camp:

Featherston, 1916-1919 (Wairarapa: Fraser Books, 2012). It has been suggested that some, or even the majority, of the prisoners at the Featherston Camp were Korean nationals or of Korean descent, although archival evidence does not seem to support this supposition. On this point, see in particular Mike Nicolaidi, The Featherston Chronicles: A Legacy of War (Auckland: Harper Collins, 1999), 121.

${ }^{4}$ Steven Bullard, Blankets on the Wire: The Cowra Breakout and its Aftermath (Canberra: Australian War Memorial, 2006), 22.

${ }^{5}$ Tilak Sareen, Japanese Prisoners of War in India, 1942-46:Bushido and Barbed Wire (Kent: Global Oriental, 2006); A. Krammer, "Japanese Prisoners of War in America," Pacific Historical Review 52, no. 1 (1983): 67-91; M. Sakihara, "Sparrows of Angel Island: The Experience of a Young Japanese Prisoner of War," Manoa 8, no. 1 (1996): 108-21.

${ }^{6}$ I. Kuznetzov, "The Situation of Japanese Prisoners of War in Soviet Camps (1945-1956)," The Journal of Slavic Military Studies 8, no. 3 (1995): 612-29.
} 
${ }^{7}$ Shinya, Beyond Death and Dishonour 43-4; Nicolaidi, The Featherston Chronicles, 18.

8 "Trades and occupations of prisoners," Papers Relating to Featherston Prisoner of War Camp, E. H Thompson Papers, fMS Papers 7014-2, Alexander Turnbull Library (ATL), Wellington; Nicolaidi,

The Featherston Chronicles, 19.

9 "Problems in Connection with Control of Japanese PsW [sic]," undated, WA112/23, Item 36, Record 4/14, Prisoner of War Camps - Featherston Prisoners Japanese Comforts, Archives New Zealand, Wellington.

${ }^{10}$ See, for example, Nicolaidi, The Featherston Chronicles, 1999; Charlotte Carr-Gregg, Japanese Prisoners of War in Revolt (Brisbane: University of Queensland Press, 1978); Charlotte Carr-Gregg, "Japanese Prisoners of War in Australia and New Zealand: The Role of Japanese Officers in the Featherston and Cowra Incidents," Political Science 29, no. 1 (1977): 29-38; Yasuhiro Ota, "Shooting and Friendship Over Japanese Prisoners of War" (master's thesis, Massey University, 2013).

${ }^{11}$ Nicolaidi, The Featherston Chronicles, 40.

12 "Problems in Connection with Control of Japanese PsW [sic]," undated, WA112/23, Item 36, Record 4/14, Prisoner of War Camps - Featherston Prisoners Japanese Comforts, Archives New Zealand, Wellington.

${ }^{13}$ Ingun Klepp and Mari Bjerck. "A Methodological Approach to the Materiality of Clothing: Wardrobe Studies," International Journal of Social Research Methodology 17, no. 4 (2014): 373-86. 14 "Convention Relative to the Treatment of Prisoners of War. Geneva, 27 July 1929." International Red Cross Conference. Accessed October 27, 2014. https://www.icrc.org/ihl/INTRO/305.

${ }^{15}$ Burge to Commandant, 14 September 1942, D306/1/80, WA112/22, Item 35, Record 4/10, Prisoner of War Camps - Featherston Clothing - Prisoners of War, Archives New Zealand, Wellington.

${ }^{16}$ Sareen, Japanese Prisoners of War in India, 203.

${ }^{17}$ Shinya, Beyond Death and Dishonour, 44.

${ }^{18}$ Nicolaidi, The Featherston Chronicles, 18; Thompson in Shinya, Beyond Death and Dishonour, 144.

${ }^{19}$ Prisoner of War Camp, Featherston. New Zealand. Department of Internal Affairs. War History Branch: Photographs relating to World War 1914-1918, World War 1939-1945, Occupation of Japan, Korean War, and Malayan Emergency. Ref: PAColl-4161-01-020-88-11. Alexander Turnbull Library, Wellington, New Zealand. http://natlib.govt.nz/records/22782304

${ }^{20}$ Cathy Casey, "Featherston Camp's Prisoners: Vivid Memories Remain (Part One)," Wairarapa Times Age, 3 August 1992.

${ }^{21}$ Burge to Commandant, 14 September 1942, D306/1/80, Burge to Commandant, 14 September 1942, D306/1/80, WA112/22, Item 35, Record 4/10, Prisoner of War Camps - Featherston Clothing - Prisoners of War, Archives New Zealand, Wellington.

${ }^{22}$ Quartermaster General to Headquarters, POW Camp, Featherston, 21 September 1942, 55/15/76/Q, WA112/22, Item 35, Record 4/10, Prisoner of War Camps - Featherston Clothing - Prisoners of War, Archives New Zealand, Wellington.

${ }^{23}$ Quartermaster General to Headquarters, POW Camp, Featherston, 18 December 1942, D213/21/2, WA112/22, Item 35, Record 4/10, Prisoner of War Camps - Featherston Clothing - Prisoners of War, Archives New Zealand, Wellington.

${ }^{24}$ Camp Quartermaster to Army HQ, Wellington, 25 December 1942, POW 20/1, WA112/22, Item 35, Record 4/10, Prisoner of War Camps - Featherston Clothing - Prisoners of War, Archives New Zealand, Wellington.

${ }^{25}$ Camp Quartermaster to Army HQ, Wellington, 6 January 1943, WA112/22, Item 35, Record 4/10, Prisoner of War Camps - Featherston Clothing - Prisoners of War, Archives New Zealand,

Wellington.

${ }^{26}$ Casey, "Featherston camp's prisoners (Part One)."

27 “Featherston P W Camp: Visit by Dr Bossard, 15-16 Dec. '43," WA112, Record 4/19, Prisoner of War Camps - Featherson - Prisoners Japanese Reports USMC [United States Marine Corps], AHQ Swiss Consul, Archives New Zealand, Wellington.

${ }^{28}$ Mitchell, Victor Leonard William, 1925-1980. [Prisoner with apron and bucket.] 1945. Ref: A-268015. Alexander Turnbull Library, Wellington, New Zealand. http://natlib.govt.nz/records/23145371 
${ }^{29}$ See, for example, Pay Office, PW1 Camp, P W Working Parties, 18 April 1945, Prisoner of War Camps: Featherston Employment, Productive Works, WA112/23, Item 36, Record 11/3/2, Archives New Zealand, Wellington; "P. W. Convention: Japanese Translation," Brigadier Ajutant General to Camp Commandant, Featherston, 24 February 1944, WA112, D366/3/2/A, Record 4/19, Prisoner of War Camps - Featherson - Prisoners Japanese Reports USMC [United States Marine Corps], AHQ Swiss Consul, Archives New Zealand, Wellington.

${ }^{30}$ Camp Quartermaster to Army HQ, Wellington, 6 January 1943, WA112/22, Item 35, Record 4/10, Prisoner of War Camps - Featherston Clothing - Prisoners of War, Archives New Zealand, Wellington.

${ }^{31}$ Camp Quartermaster to Army HQ, Wellington, 19 January 1943, WA112/22, Item 35, Record 4/10, Prisoner of War Camps - Featherston Clothing - Prisoners of War, Archives New Zealand, Wellington.

${ }^{32}$ Camp Commandant to Army HQ, Wellington, 20 January 1943, WA112/22, Item 35, Record 4/10, Prisoner of War Camps - Featherston Clothing - Prisoners of War, Archives New Zealand, Wellington.

${ }^{33}$ Army HQ, Wellington, to Camp Commandant, 28 January 1943, 55/95/Q, WA112/22, Item 35, Record 4/10, Prisoner of War Camps - Featherston Clothing - Prisoners of War, Archives New Zealand, Wellington.

${ }^{34}$ Minute Sheet, Japanese PW Clothing etc, 21 April 1943, D336/3/24/02, WA112/22, Item 35, Record 4/10, Prisoner of War Camps - Featherston Clothing - Prisoners of War, Archives New Zealand, Wellington.

${ }^{35}$ Burge to Commandant, 14 September 1942, D306/1/80, WA112/22, Item 35, Record 4/10, Prisoner of War Camps - Featherston Clothing - Prisoners of War, Archives New Zealand, Wellington.

${ }^{36}$ Adjutant, P W Camp, Memorandum for Quartermaster, Guards, and Captain Ashton, 13 April 1943, WA112/22, Item 35, Record 4/10, Prisoner of War Camps - Featherston Clothing - Prisoners of War, Archives New Zealand, Wellington.

${ }^{37}$ District Commandant, Central Military District to Army Headquarters, Wellington, 18 March 1943, 69/30/18, Record 319/4/65, Staff POW (Prisoner of War) Camp, Featherston, Archives New Zealand, Wellington.

${ }^{38}$ Cathy Casey, "Featherston Camp's Prisoners: Vivid Memories Remain (Part Two)." Wairarapa Times Age, 4 August 1992.

${ }^{39}$ Senior Interpreter Captain Ashton to Prisoners of War, "Worn Out Clothing," 4 May 1943, WA112/22, Item 35, Record 4/10, Prisoner of War Camps - Featherston Clothing - Prisoners of War, Archives New Zealand, Wellington [cited from the English language version].

${ }^{40}$ Minute Sheet, Japanese PW Clothing etc, 21 April 1943, D336/3/24/02, WA112/22, Item 35, Record 4/10, Prisoner of War Camps - Featherston Clothing - Prisoners of War, Archives New Zealand, Wellington.

${ }^{41}$ A Camp Guard Officer, Lt. Dave Gillies, "Featherston POW Camp," Wairarapa Remembers: Our District During World War Two, undated, Wairarapa Archive, Masterton.

${ }^{42}$ Schmidt, Consul of Switzerland in Charge of Japanese Interests, to Adjutant-General, 21 December 1943, WA112, Record 4/19, Prisoner of War Camps - Featherson - Prisoners Japanese Reports USMC [United States Marine Corps], AHQ Swiss Consul, Archives New Zealand, Wellington.

${ }^{43}$ A Camp Guard Officer, Lt. Dave Gillies, "Featherston POW Camp."

${ }^{44}$ Quartermaster General, Wellington, to Camp Commandant, 24 March 1944, "Court of Enquiry No. 1 P. W. Camp Distinctive Coloured Patch for PW Uniforms," 68/20/1/Q, WA1 12/22, Item 35, Record 4/10, Prisoner of War Camps - Featherston Clothing - Prisoners of War, Archives New Zealand, Wellington.

${ }^{45}$ Casey, "Featherston Camp's Prisoners (Part Two)."

${ }^{46}$ Shinya, Beyond Death and Dishonour, 71.

47 "Trades and occupations of prisoners," ALT.; Casey, "Featherston Camp's Prisoners (Part Two)."

${ }^{48}$ Commandant to Army Headquarters, Wellington, 2 July 1944, WA112/22, Item 35, Record 4/10,

Prisoner of War Camps - Featherston Clothing - Prisoners of War, Archives New Zealand,

Wellington. 
${ }^{49}$ Quartermaster General, Wellington, to Camp Commandant, 6 April 1944, "Court of Enquiry - No. 1 P.W. Camp Distinctive Coloured Patch for PW Uniforms," 68/20/1/Q, WA112/22, Item 35, Record 4/10, Prisoner of War Camps - Featherston Clothing - Prisoners of War, Archives New Zealand, Wellington.

${ }^{50}$ Camp Commandant to Quartermaster General, Wellington, WA112/22, Item 35, Record 4/10, Prisoner of War Camps - Featherston Clothing - Prisoners of War, Archives New Zealand, Wellington.

${ }^{51}$ Quartermaster General, Wellington, to Camp Commandant, 3 May 1944, "P. W. Uniforms Coloured Patches," 68/20/1/Q, WA112/22, Item 35, Record 4/10, Prisoner of War Camps Featherston Clothing - Prisoners of War, Archives New Zealand, Wellington.

52 "Convention Relative to the Treatment of Prisoners of War."

${ }^{53}$ Commandant to Army Headquarters, Wellington, "Officer - P W Dress," 15 April 1944, WA112/22, Item 35, Record 4/10, Prisoner of War Camps - Featherston Clothing - Prisoners of War, Archives New Zealand, Wellington.

${ }^{54}$ Quartermaster General to Headquarters, Featherston Camp, "Officers - P W Dress," 4 May 1944, 61/57/Q, WA112/22, Item 35, Record 4/10, Prisoner of War Camps - Featherston Clothing Prisoners of War, Archives New Zealand, Wellington.

${ }^{55}$ Commandant to Quartermaster General, "P W Officers - Dress," 10 May 1944, WA1 12/22, Item 35, Record 4/10, Prisoner of War Camps - Featherston Clothing - Prisoners of War, Archives New Zealand, Wellington.

${ }^{56}$ Commandant to Army Headquarters, Wellington, "P W Uniforms - Coloured Patches," 30 June 1944, WA112/22, Item 35, Record 4/10, Prisoner of War Camps - Featherston Clothing - Prisoners of War, Archives New Zealand, Wellington.

${ }^{57}$ Adjutant-General to Commandant, "Identification of PW," 29 June 1944, WA112/22, Item 35, Record 4/10, Prisoner of War Camps - Featherston Clothing - Prisoners of War, Archives New Zealand, Wellington.

${ }^{58}$ Commandant to Adjutant-General, "Identification of PW," 2 July 1944, WA112/22, Item 35, Record 4/10, Prisoner of War Camps - Featherston Clothing - Prisoners of War, Archives New Zealand, Wellington.

${ }^{59}$ Adjutant-General to Commandant, "Identification of PW," 12 July 1944, D.336/2/24A,WA112/22, Item 35, Record 4/10, Prisoner of War Camps - Featherston Clothing - Prisoners of War, Archives New Zealand, Wellington.

${ }^{60}$ Japanese prisoners of war working at the state market gardens, near Featherston. John Dobree Pascoe, 1908-1972: Photographic albums, prints and negatives. Ref: 1/4-000760-F. Alexander Turnbull Library, Wellington, New Zealand. http://natlib.govt.nz/records/22333872

${ }^{61}$ Commandant to Army Headquarters, Wellington, "Identification of PW," 16 July 1944, WA112/22, Item 35, Record 4/10, Prisoner of War Camps - Featherston Clothing - Prisoners of War, Archives New Zealand, Wellington.

${ }^{62}$ Shinya, Beyond Death and Dishonour, 58.

${ }^{63}$ Commandant to Army Headquarters, Wellington, "Identification of PW," 16 July 1944, WA112/22, Item 35, Record 4/10, Prisoner of War Camps - Featherston Clothing - Prisoners of War, Archives New Zealand, Wellington.

${ }^{64}$ Commandant to Army Headquarters, Wellington, "Identification of PW," 21 July 1944, WA1 12/22, Item 35, Record 4/10, Prisoner of War Camps - Featherston Clothing - Prisoners of War, Archives New Zealand, Wellington.

${ }^{65}$ Commandant to Army Headquarters, Wellington, "Identification of PW," 16 July 1944, WA112/22, Item 35, Record 4/10, Prisoner of War Camps - Featherston Clothing - Prisoners of War, Archives New Zealand, Wellington.

${ }^{66}$ Assistant Adjutant General to Commandant, "Identification of PW," 18 July 1944, 68/20/1/A, WA112/22, Item 35, Record 4/10, Prisoner of War Camps - Featherston Clothing - Prisoners of War, Archives New Zealand, Wellington.

${ }^{67}$ Assistant Adjutant General to Commandant, "Identification of PW," 18 July 1944, 68/20/1/A, WA112/22, Item 35, Record 4/10, Prisoner of War Camps - Featherston Clothing - Prisoners of War, Archives New Zealand, Wellington. 
68 "Problems in Connection with Control of Japanese PsW [sic]," undated, WA112/23, Item 36, Record 4/14, Prisoner of War Camps - Featherston Prisoners Japanese Comforts, Archives New Zealand, Wellington.

${ }^{69}$ Commandant to Army Headquarters, Wellington, "Identification of Japanese PW," 4 August 1944, Item 35, Record 4/10, Prisoner of War Camps - Featherston Clothing - Prisoners of War, Archives New Zealand, Wellington.

${ }^{70}$ Shinya, Beyond Death and Dishonour, 123-24. 